\title{
Cross-cultural adaptation to Portuguese of a measure of satisfaction with participation of the Patient-Reported Outcomes Measurement Information System (PROMIS ${ }^{\circledR}$ )
}

\author{
Adaptação transcultural para o português da medida de satisfação com a \\ participação do Patient-Reported Outcomes Measurement Information System \\ $\left(\right.$ PROMIS $^{\circledR}$ )
}

Maria Cristina Lima e Silva, ${ }^{1}$ Tânia Maria da Silva Mendonça, ${ }^{2}$ Carlos Henrique Martins da Silva, ${ }^{3}$ Rogério de Melo Costa Pinto ${ }^{4}$

\begin{abstract}
Background: Mental disorders often impair functioning in several areas of life and lead to unhappiness and suffering that may affect health-related quality of life (HRQoL). Satisfaction with participation is an indicator of HRQoL, and its measurement by patients reflects the impact of disease on their social, emotional and professional life. The Patient-Reported Outcomes Measurement Information System (PROMIS ${ }^{\circledR}$ ) offers an item bank based on item response theory. This system provides efficient, reliable and valid self-report instruments of satisfaction with participation, a measure that is both scarce and useful in the assessment of mental disorder outcomes.

Objective: To cross-culturally adapt the PROMIS ${ }^{\circledR}$ satisfaction with participation item bank to Portuguese.

Methods: Cross-cultural adaptation followed the Functional Assessment of Chronic Illness Therapy (FACIT) multilingual translation method and was achieved through steps of forward and backward translations, review by bilingual experts (one of them a native of Portugal) and pretesting in a group of 11 adult native Brazilians. Instrument adaptation followed a universal approach to translation, with harmonization across languages.

Results: Equivalence of meaning was achieved. As two of the 26 translated items, which asked about leisure and social activities, were not understood by less educated participants, an explanation in parentheses was added to each item, and the problem was solved. All items were appropriate and did not cause embarrassment to the participants.

Conclusions: The satisfaction with participation item bank is culturally and linguistically suitable to be used in Brazil. After the pretest is applied in Portugal and in other Portuguese-speaking countries, the same instrument will be ready to be used in multinational studies. Keywords: Mental disorders, outcome assessment, social participation, translation, item response theory.
\end{abstract}

\section{Resumo}

Introdução: Os transtornos mentais quase sempre prejudicam o desempenho em vários domínios da vida e resultam em infelicidade e sofrimento que podem afetar a qualidade de vida relacionada à saúde (QVRS). A satisfação com a participação é um indicador de QVRS, e sua medida, do ponto de vista do paciente, reflete o impacto da doença em sua vida social, emocional e profissional. O banco de itens Patient-Reported Outcomes Measurement Information System (PROMIS ${ }^{\circledR}$ ) foi fundamentado na teoria da resposta ao item. O sistema proporciona autorrelatos eficientes, confiáveis e válidos de satisfação com a participação, uma medida escassa e útil na avaliação dos desfechos de transtornos mentais. Objetivo: Adaptar transculturalmente para o português o banco de itens de satisfação com a participação do PROMIS ${ }^{\circledR}$.

Métodos: A adaptação transcultural seguiu a metodologia de tradução multilíngue do Functional Assessment of Chronic Illness Therapy (FACIT). Incluiu traduções, retrotraduções, revisões por especialistas bilíngues (um deles nativo de Portugal) e pré-teste com 11 brasileiros adultos nativos. A adaptação do instrumento seguiu uma abordagem universal de tradução, com harmonização entre as línguas. Resultados: A equivalência de significado foi atingida. Dois dos 26 itens traduzidos, referindo-se a laser e atividades sociais, não foram compreendidos pelos participantes com menor escolaridade. Nesses casos, uma explicação entre parênteses foi adicionada aos itens, solucionando o problema. Todos os itens foram apropriados e não causaram constrangimento aos participantes. Conclusões: $O$ banco de itens satisfação com a participação é cultural e linguisticamente adequado para ser utilizado no Brasil. A realização do pré-teste em Portugal e em outros países lusófonos possibilitará a utilização de um mesmo instrumento em estudos multinacionais.

Descritores: Desordens mentais, avaliação de resultados, participação social, tradução, teoria da resposta ao item.

\footnotetext{
${ }^{1}$ Health-Related Quality of Life Research Group and Department of Anesthesiology, Universidade Federal de Uberlândia (UFU), Uberlândia, MG, Brazil. ${ }^{2}$ HealthRelated Quality of Life Research Group and School of Physical Therapy, UFU, Uberlândia, MG, Brazil. ${ }^{3}$ Health-Related Quality of Life Research Group and Medical School, UFU, Uberlândia, MG, Brazil. ${ }^{4}$ Health-Related Quality of Life Research Group and Department of Mathematics, UFU, Uberlândia, MG, Brazil. Financial support: Fundação de Amparo à Pesquisa do Estado de Minas Gerais (FAPEMIG).

Submitted Jul 31 2014, accepted for publication Feb 04 2015. No conflicts of interest declared concerning the publication of this article.

Suggested citation: Lima e Silva MC, Mendonça TM, da Silva CH, Pinto RM. Cross-cultural adaptation to Portuguese of a measure of satisfaction with participation of the Patient-Reported Outcomes Measurement Information System (PROMIS ${ }^{\circledR}$ ). Trends Psychiatry Psychother. 2015;37(2):94-99. http:// dx.doi.org/10.1590/2237-6089-2014-0035
} 


\section{Introduction}

Mental disorders often impair functioning in several areas of life and lead to unhappiness and suffering that may affect health-related quality of life (HRQoL). ${ }^{1}$ Satisfaction with participation is an indicator of HRQoL, and its measurement by the patients reflects the impact of the disease on their social, emotional and professional life. The assessment of the extent of mental disorder impact may help healthcare professionals to prescribe and evaluate therapies. ${ }^{2}$ However, there are few instruments for such measurements, ${ }^{3}$ particularly in Brazil, despite the high prevalence of mental disorders in this country. ${ }^{4}$

Functioning and social well-being should be assessed using instruments that provide information about effectiveness and cost-effectiveness and that give results that may be extrapolated from one setting to another because research has become international. Therefore, an instrument addressing satisfaction in social contexts has been adapted for use in Brazil and Portugal, but only in educational settings. ${ }^{5}$ In public health, the PatientReported Outcomes Measurement Information System (PROMIS ${ }^{\circledR}$ ) item bank for satisfaction with participation is a novel, state-of-the-art system to measure the impact of mental disorders on HRQoL. ${ }^{6-8}$

PROMIS $^{\circledR}$ has been developed to overcome the limitations of traditional HRQoL instruments and to ensure measure standardization, precision and comparability. Unlike conventional instruments and fixed scales, PROMIS ${ }^{\circledR}$ provides several item banks that may be used to assess the physical and psychosocial dimensions of health. ${ }^{9}$ Each item bank may be applied independently according to the needs of researchers. The item banks are in the public domain and based on item response theory and computer adaptive testing (CAT), and, therefore, ensure greater flexibility and measure precision and conciseness, reduce respondent burden and enable comparisons of the same attribute in smaller samples of different populations without losing statistical power. ${ }^{10}$

Assessments may be conducted using several instruments, from the fixed-length paper-based questionnaire to the dynamic CAT tool, available in a web site where the results are displayed and stored. ${ }^{11}$

The item banks were originally created in English, and their use in other cultural contexts requires a systematic process of translation and cultural adaptation to produce valid, reliable and comparable measures. ${ }^{12,13}$ The translation method specified by PROMIS ${ }^{\circledR}$ for its item banks follows a universal approach to produce a single version for countries that speak the same language. ${ }^{14-16}$

This study translated and adapted the PROMIS ${ }^{\circledR}$ satisfaction with participation item bank to Portuguese.

\section{Method}

\section{Description of the satisfaction with participation item bank}

This bank has 26 items to assess the effect of chronic diseases and their treatments on individual satisfaction with participation in the contexts of family, friends, work and leisure. A Likert-like scale ranging from 1 (not at all) to 5 (very much) was used for responses. The bank has two facets: satisfaction with participation in social roles (14 items) and satisfaction with discretionary social activities (12 items). All items rely on seven-day recall and are linked to the social health component of PROMIS ${ }^{\circledR}$, based on the perception of well-being in social activities and relationships, including the ability to relate to individuals, groups, communities and society as a whole. ${ }^{7}$

\section{Preparation for cross-cultural adaptation}

Authorization was obtained from the PROMIS ${ }^{\circledR}$ administrative center to translate version 1.0 of the satisfaction with participation item bank. The study was approved by the Ethics Committee of Universidade Federal de Uberlândia (UFU), Minas Gerais, Brazil. The selected translators received the PROMIS $^{\circledR}$ technical definitions of terms and concepts to be measured in each item.

\section{Cross-cultural adaptation}

PROMIS ${ }^{\circledR}$ recommends the Functional Assessment of Chronic Illness Therapy (FACIT) multilingual translation method because it approaches the three dimensions of cross-cultural equivalence of meaning: semantic (the meaning of the item is the same in the source and target language), cultural (the item is relevant to both cultures) and conceptual (the translated item measures the same theoretical construct as the source item). ${ }^{14}$ This method is consistent with the guidelines recommended by the International Society of Pharmacoeconomics and Outcomes Research (ISPOR) ${ }^{13}$ and consists of translation followed by a pretest with cognitive debriefing of the translated items. A universal approach with harmonization across Brazilian and European Portuguese guided the translation to produce a single version for both countries. ${ }^{14}$ Portugal was included in the translation for Brazil because together they account for most Portuguese speakers in the world, and because it would be easier to contact a linguist from Portugal than from other Portuguesespeaking countries. 


\section{Translation}

The FACIT translation method and the purpose of each step are summarized below:

1) Forward translation: Source items in English were translated into Portuguese by two professional independent native translators to ensure the inclusion of more than one personal writing style and different language habits.

2) Reconciliation: An independent native Portuguese translator reconciled the two forward translations to solve discrepancies and reach a consensus.

3) Back-translation: A native English-speaking translator, fluent in Portuguese and blinded to the previous steps, back translated the reconciled version. This translator was instructed to capture the literal meaning of the item to control the quality of reconciliation.

4) Quality assurance of the back-translation: A native English speaking FACIT language coordinator, fluent in Portuguese, compared the back-translation and the source text to detect discrepancies and issue comments to reviewers to elucidate the intent of each item.

5) Independent reviews: Four bilingual experts (three Brazilian and one Portuguese) examined all previous steps to select the most appropriate translation for each item or develop an alternative translation in case the options provided were all inappropriate.

6) Pre-finalization review: A FACIT language coordinator checked the discrepancies between translations detected by the reviewers and issued comments about them to the Portuguese language coordinator.

7) Finalization process: The Portuguese language coordinator defined the final translation, provided both a literal and an improved back-translation by reviewing the previous steps and prepared comments to be sent to the FACIT language coordinator.

8) Harmonization and quality assurance: The FACIT language coordinator checked the equivalence of the final translation and item consistency in all reports in collaboration with the PROMIS ${ }^{\circledR}$ Statistical Center. The Portuguese language coordinator was consulted again for additional opinions, if required.

9) Formatting and proofreading: Two independent proofreaders and a reconciler, both appointed by FACIT, checked all items for spelling and grammar and formatted them as a questionnaire.

\section{Pretesting of translation}

Pretesting consists of a qualitative assessment of the translated items by native speakers of the target language to identify and correct errors that may affect the equivalence of meaning with the source language and ensure that the translation is clear to understand. The technique used was cognitive debriefing interviews with retrospective verbal probing. ${ }^{14}$ Before the interview, a convenience sample of 11 Brazilians were selected. They were 18 years or older, of both sexes and varied ages and different educational levels, but all able to read and write. They were undergoing treatment at Hospital de Clínicas da Universidade Federal de Uberlândia and responded a paper-andpencil version of the questionnaire independently after signing an informed consent term. After that, a trained healthcare interviewer used a specific script suggested by FACIT to ask participants to rephrase the items in their own words and define phrases and words that were problematic in the translated text. All items were included in at least five cognitive interviews. Information collected during the cognitive interviews was later used to assess the appropriateness, ease to understand and acceptability of the final Portuguese version.

\section{Results}

\section{Translation}

During the translation, all the steps were followed by each translator. Results showed a consistent translation with equivalence of meaning. The major challenge of the translation phase was to harmonize some lexical and syntactic inconsistencies between Brazilian and European Portuguese. The expression "run errands" in the statement "I am satisfied with my ability to run errands" was translated into Brazilian Portuguese as "pequenas tarefas fora de casa" and as "recados" in European Portuguese. When harmonizing translation, the Brazilian expression prevailed, as it was equivalent in both cultures. In the syntactic field, there were differences in pronoun placement. The use of pronouns placed before the verb, as in "Eu me sinto," prevailed in Brazilian translations, whereas the Portuguese version only had pronouns placed after the verb, as in "Sinto-me," which prevailed in the harmonization because this position is common to both cultures. Another syntactic difference was found in the use of the gerund and infinitive of the verbs to work and to visit. The Brazilian translation had both verbs in the gerund, as in "tempo que passo trabalhando" and "tempo que passo visitando," whereas the Portuguese translation had the infinitive, as in "tempo que passo 
a trabalhar" and "tempo que passo a visitar." In the harmonization, the gerund prevailed, because, unlike the Portuguese, Brazilians used only this form. Finally, the use of definite articles before possessive pronouns was kept in 17 items, as it was optional for Brazilians, but necessary for the Portuguese.

Table 1 shows the steps of the FACIT translation of one item.

Table 1 - Satisfaction with participation in social roles (SRPSAT08) item history

\begin{tabular}{ll}
\hline English & I feel good about my ability to do things for my family. \\
Forward 1 & Eu me sinto bem com minha habilidade de fazer coisas para a minha família. \\
Forward 2 & Eu me sinto bem com minha habilidade de fazer coisas para a minha família. \\
Reconciliation & Eu me sinto bem com a minha capacidade de fazer coisas para minha família. \\
Back-translation & I feel good about my ability to do things for my family. \\
FACIT comments & 1. Is it necessary to use "Eu" at the beginning of the item? \\
& 2. "Sinto-me" would be more universal and appropriate for Portugal. \\
& 3. Please, evaluate whether to use "por" or "para." \\
& 4. In Portugal it would be more appropriate to say "para a minha," "por a minha" or "pela minha," \\
depending on the meaning (related to the discussion of whether to use "por" or "para").
\end{tabular}

Reviewer-1 (Brazilian) Reconciliation OK.

For Brazilians, it is more natural to use "eu me sinto bem" instead of "sinto-me bem." In this context, "por" or "para" means the same thing.

Reviewer-2 (Brazilian) Eu me sinto bem com a minha habilidade em fazer coisas pela minha família.

1. Yes, " $E u$ " is required at the beginning of each item by Portuguese grammar.

2. The pronoun " $m e^{\prime \prime}$ is required in Portugal. In Brazil, placement before the verb is more natural.

3. We may use "por," "para" or "pela," depending on the context.

4. Here in Brazil, translation depends on the context.

Reviewer-3 (Brazilian) Eu me sinto bem com minha capacidade de fazer coisas para minha familia.

1. In Brazil, reflexive pronouns are usually placed before the verb. In this case, "eu" is necessary for the item to be grammatically correct: "Eu me sinto."

2. In Brazil, "Eu me sinto" is more appropriate. "Sinto-me" is too formal.

3. Both mean the same thing but "para" is more used in Brazil.

4. In Brazil, we do not use definite articles before possessive pronouns.

Reviewer-4 (Portuguese) Sinto-me bem com a minha capacidade de fazer coisas para a minha família.

- "Eu me sinto..." is unacceptable for Portugal, "Sinto-me bem com a minha capacidade de fazer coisas para a minha família" is ok. Alternatively, use a different structure: "Sinto prazer com a minha capacidade de fazer coisas para a minha família" - Literal BT: "[I] feel pleasure with my capacity of doing things for my family."

Target language coordinator comments

I think "capacidade" is a better translation for "ability" in this context. It means you can do something. "Habilidade" means that you can do something very well, like a talent. I think that is not what the item is supposed to evaluate.

In Brazil, "Sinto-me" is too formal. "Sinto prazer" also does not work in this context. I think that it is an irreconcilable difference between Brazil and Portugal.

Final

Eu me sinto bem com minha capacidade de fazer coisas para minha família.

Literal back-translation of final I feel well with my capacity of doing things for my family.

Improved back-translation of final I feel good with my ability to do things for my family.

Harmonization issues

Please note that the anxiety and depression banks were recently finalized using Sinto-me for I feel. We need to be consistent across banks.

Target language coordinator

OK. We can use "sinto-me" for "I feel" for the sake of universality and consistency.

comments

Harmonization issues

Can we add the article "a": "Sinto-me bem com a minha capacidade de fazer coisas para a minha família"?

Target language coordinator comments

OK. In Brazil, the use of the article in this context is optional.

Post harmonization final

Sinto-me bem com a minha capacidade de fazer coisas para a minha família.

Post proofing final

Not applicable.

Posttest final

Sinto-me bem com a minha capacidade de fazer coisas para a minha família.

FACIT $=$ Functional Assessment of Chronic Illness Therapy. 


\section{Pretest of translation}

Mean age of the 11 pretest participants was 50 years (range 23-67), and 55\% were women. They answered the self-administered questionnaire consistently and quickly. The interview for general assessment of the items revealed that no items were considered inappropriate or offensive. Seventy-three percent of the participants did not mentioned any difficulty in understanding the 26 items; the $27 \%$ that reported difficulties had less than nine years of education. Two items were amended after the retrospective cognitive interviews. Explanatory parentheses were added to the statements "Estou satisfeito(a) com a quantidade de tempo que passo fazendo atividades de lazer (atividades de tempo livre)" and "Estou satisfeito(a) com a quantidade de atividades sociais (atividades em que se convive com outras pessoas) que tenho atualmente" to explain leisure and social activities.

\section{Discussion}

This study produced a relevant and linguisticequivalent patient-reported outcome measure in a language other than English. Therefore, underrepresented groups whose language is not English may be included in studies in this area, and this measure may enable the conduction of cross-cultural studies in the field of Psychiatry.

Strict application of the FACIT method, supported by scientific evidence ${ }^{12,14,15}$ and defined in the ISPOR guidelines ${ }^{13,16}$ to validate patient-reported outcome measures, resulted in a high quality translation of the satisfaction with participation item bank. The 26 items were well accepted, and only two (7.6\%) required minor adjustments to improve understanding of the abstract terms social activities and leisure activities according to the results of the pretest.

Although some back-translations lacked the required literal equivalence, the step was not repeated, and the results were not compromised. During subsequent steps, all final statements were revised individually by multiple reviewers. The process was accelerated, which is an advantage of this method, and this may decrease hesitation bias, characterized by translation distortions that occur when translators are exposed to the criticism of others, or share the same worldview of their peers. ${ }^{15}$

Native Brazilian and Portuguese reviewers participated in the independent review phase, as recommended by the method, to ensure a universal approach. The collaboration of the Portuguese reviewer contributed to the semantic harmonization between
Brazilian and European Portuguese. Expressions that were concurrently used in both cultures prevailed in harmonization. Further qualitative evaluation of the items by native people of Portugal will enable the use of the same instrument in both countries. The advantage of using the same translation in a cross-cultural study is the lower susceptibility to bias than when applying countryspecific versions created by different individuals. ${ }^{14}$

The version described here is not universally applicable to Portuguese-speaking countries other than Brazil and Portugal. To be used in other countries, the Brazilian version should be adapted to their populations and their respective cultures. ${ }^{16}$ However, translation and cultural adaptation will be easier and faster, as the items have already been translated from English into Portuguese, and only adaptations to different Lusophone cultures will be required.

According to this study, the Portuguese version of the satisfaction with participation item bank is culturally and linguistically appropriate for the Brazilian context. A study to validate its psychometric properties is underway in Brazil, and results will ensure the applicability of the items in the Brazilian population.

\section{References}

1. World Health Organization (WHO). The world health report 2001 - Mental health: new understanding, new hope. Geneva: WHO; 2001.

2. Hahn EA, Cella D, Bode RK, Hanrahan RT. Measuring social well-being in people with chronic illness. Soc Indic Res. 2010;96:381-401.

3. Hahn EA, Cella D, Bode RK, Rosenbloom SK, Taft R. Social well-being: the forgotten health status measure. Qual Life Res. 2005; 14:1991.

4. Santos EG, Siqueira MM. Prevalência dos transtornos mentais na população adulta brasileira: uma revisão sistemática de 1997 a 2009. J Bras Psiquiatr. 2010;59:238-46.

5. Marôco JP, Campos JA, Vinagre MG, Pais-Ribeiro JL. Adaptação Transcultural Brasil-Portugal da Escala de Satisfação com o Suporte Social para Estudantes do Ensino Superior. Psicol Reflex Crit. 2014;27:247-56.

6. Cella D, Yont S, Rothrock N, Gershon R, Cook K, Reeve B, et al. The Patient-Reported Outcomes Measurement Information System (PROMIS): progress of an NIH Roadmap cooperative group during its first two years. Med Care. 2007;45:S3-S11.

7. Hahn EA, Devellis RF, Bode RK, Garcia SF, Castel LD, Eisen SV, et al. Measuring social health in the Patient-Reported Outcomes Measurement Information System (PROMIS): item bank development and testing. Qual Life Res. 2010;19:1035-44.

8. Riley WT, Pilkonis P, Cella D. Application of the National Institutes of Health Patient-Reported Outcomes Measurement Information System (PROMIS) to mental health research. J Ment Health Policy Econ. 2011;14:201-8.

9. Fries JF, Bruce B, Cella D. The promise of PROMIS: using item response theory to improve assessment of patient-reported outcomes. Clin Exp Rheumatol. 2005;23:S53-7.

10. Alonso J, Bartlett SJ, Rose M, Aaronson NK, Chaplin JE, Efficace $F$, et al. The case for an international Patient-Reported Outcomes Measurement Information System (PROMIS ${ }^{\circledR}$ ) initiative. Health Qual Life Outcomes. 2013;11:210.

11. Gershon RC, Rothrock N, Hanrahan R, Bass M, Cella D. The use of PROMIS and assessment center to deliver patientreported outcome measures in clinical research. J Appl Meas. 2010;11:304-14. 
12. Guillemin F, Bombardier C, Beaton D. Cross-cultural adaptation of health-related quality of life measures: literature review and proposed guidelines. J Clin Epidemiol. 1993;46:1417-32.

13. Wild $D$, Grove $A$, Martin M, Eremenco $S$, McElroy $S$, VerjeeLorenz A, et al. Principles of good practice for the translation and cultural adaptation process for patient-reported outcomes (PRO) measures: report of the ISPOR Task Force for Translation and Cultural Adaptation. Value Health. 2005;8:94-104.

14. Eremenco SL, Cella D, Arnold B]. A comprehensive method for the translation and cross-cultural validation of health status questionnaires. Eval Health Prof. 2005;28:212-32.

15. Bonomi AE, Cella DF, Hahn EA, Bjordal K, Sperner-Unterweger $B$, Gangeri $L$, et al. Multilingual translation of the Functional Assessment of Cancer Therapy (FACIT) quality of life measurement system. Qual Life Res. 1996;5:309-20.
16. Wild D, Eremenco S, Mear I, Martin M, Houchin C, Gawlicki M, et al. Multinational trials-recommendations on the translations required, approaches to using the same language in different countries, and the approaches to support pooling the data: the ISPOR Patient-Reported Outcomes Translation and Linguistic Validation Good Research Practices Task Force report. Value Health. 2009;12:430-40.

\section{Correspondence:}

Maria Cristina Lima e Silva

Rua Javari, 338, Bairro Lídice

38400-146 - Uberlândia, MG - Brazil

E-mail: maria.crist@hotmail.com 